\section{A NEW UNDERGROUND MONSTER}

A RECENT communication from Fritz Müller, of Itajahy, in Southern Brazil, to the Zoologische Garten contains a wonderful account of the supposed existence of a gigantic earthworm in the highlands of the southern provinces of Brazil, where it is known as the "Minhocao." The stories told of this supposed animal, says Fritz Müller, sound for the most part so incredible, that one is tempted to consider them as fabulous. Who could repress a smile at hearing men speak of a worm some fifty yards in length, and five in breadth, covered with bones as with a coat of armour, uprooting mighty pine trees as if they were blades of grass, diverting the courses of streams into fresh channels, and turning dry land into a bottomless morass? And yet after carefully considering the different accounts given of the "Minhocao," one can hardly refuse to believe that some such animal does really exist, although not quite so large as the country folk would have us to believe.

About eight years ago a "Minhocao" appeared in the neighbourhood of Lages. Francisco de Amaral Varella, when about ten kilometres distant from that town, saw lying on the bank of the Rio das Caveiras a strange animal of gigantic size, nearly one metre in thickness, not very long, and with a snout like a pig, but whether it had legs or not he could not tell. $\mathrm{He}$ did not dare to seize it alone, and whilst calling his neighbours to his assistance, it vanished, not without leaving palpable marks behind it in the shape of a trench as it disappeared under the earth. A week later a similar trench, perhaps constructed by the same animal, was seen on the opposite side of Lages, about six kilometres distant from the former, and the traces were followed, which led ultimately under the roots of a large pine tree, and were lost in the marshy land. Herr F. Kelling, from whorn this information was obtained, was at that time living as a merchant in Lages, and saw himself the trenches made by the "Minhocao." Herr E. Odebrecht, while surveying a line of road from Itajahy into the highlands of the province of Santa Caterina, several years ago, crossed a broad marshy plain traversed by an arm of the river Marombas. His progress here was much impeded by devious winding trenches which followed the course of the stream, and occasionally lost themselves in it. At the time Herr Odebrecht could not understand the origin of these peculiar trenches, but is now inclined to believe that they were the work of the "Minhocao."

About fourteen years ago, in the month of January, Antonio José Branco, having been absent with his whole family eight days from his house, which was situated on one of the tributaries of the Rio dos Cachorros, ten kilometres from Curitibanos, on returning home found the road undermined, heaps of earth being thrown up, and large trenches made. These trenches commenced at the source of a brook, and followed its windings; terminating ultimately in a morass after a course of from 700 to $1, \infty 00$ metres. The breadth of the trenches was said to be about three metres. Since that period the brook has flowed in the trench made by the "Minhocao." The path of the animal lay generally beneath the surface of the earth under the bed of the stream; several pine trees had been rooted up by its passage. One of the trees from which the Minhocao in passing had torn off the bark and part of the wood, was said to be still standing and visible last year. Hundreds of people from Curitibanos and other places had come to see the devastation caused by the Minhocao, and supposed the animal to be still living in the marshy pool, the waters of which appeared at certain times to be suddenly and strangely troubled. Indeed on still nights a rumbling sound like distant thunder and a slight movement of the earth was sensible in the neighbouring dwellings. This story was told to Herr Miller by two eye-witnesses, José, son of old Branco, and a step- son, who formerly lived in the same house. Herr Muiller, remarks that the appearance of the Minhocao is always supposed to presage a period of rainy weather.

In the neighbourhood of the Rio dos Papagaios, in the province of Paranà, one evening in I 849 after a long course of rainy weather, a sound was heard in the house of a certain João de Deos, as if rain were again falling in a wood hard by, but on looking out, the heavens were seen to be bright with stars. On the following morning it was discovered that a large piece of land on the further side of a small hill had been entirely undermined, and was traversed by deep trenches which led towards a bare open plateau covered with stones, or what is called in this district a "legeado." At this spot large heaps of clay turned up out of the earth marked the onward course of the animal from the legeado into the bed of a stream running into the Papagaios. Three years after this place was visited by Senhor Lebino José dos Santos, a wealthy proprietor, now resident near Curitibanos. He saw the ground still upturned, the mounds of clay on the rocky plateau, and the remains of the moved earth in the rocky bed of the brook quite plainly, and came to the conclusion that it must have been the work of two animals, the size of which must have been from two to three metres in breadth.

In the same neighbourhood, according to Senhor Lebino, a Minhocao had been seen several times before. A black woman going to draw water from a pool near a house one morning, according to her usual practice, found the whole pool destroyed, and saw a short distance off an animal which she described as being as big as a house moving off along the ground. The people whom she summoned to see the monster were too late, and found oniy traces of the animal, which had apparently plunged over a neighbouring cliff into deep water. In the same district a young man saw a huge pine suddenly overturned, when there was no wind and no one to cut it. On hastening up to discover the cause, he found the surrounding earth in movement, and an enormous wormlike black animal in the middle of it, about twenty-five metres long, and with two horns on its head.

In the province of São Paulo, as Senhor Lebino also states, not far from Ypanema, is a spot that is still called Charquinho, that is, Little Marsh, as it formerly was, but some years ago a Minhocao made a trench through the marsh into the Ypanema River, and so converted it into the bed of a stream.

In the year 1849 , Senhor Lebino was on a journey near Arapehy, in the State of Uruguay. There he was told that there was a dead Minhocao to be seen a few miles off, which had got wedged into a narrow cleft of a rock, and so perished. Its skin was said to be as thick as the bark of a pine-tree, and formed of hard scales like those of an armadillo:

From all these stories it would appear conclusive that in the high district where the Uruguay and the Paranà have their sources, excavations, and long trenches are met with, which are undoubtedly the work of some living animal. Generally, if not always, they appear after continued rainy weather, and seem to start from marshes or river-beds, and to enter them again. The accounts as to the size and appearance of the creature are very uncertain. It might be suspected to be a gigantic fish allied to Lepidosiren and Ceratodus ; the "swine's snout," would show some resemblance to Ceratodus, while the horns on the body rather point to the front limbs of Lepidosiren, if these particulars can be at all depended upon. In any case, concludes Herr Müller, it would be worth while to make further investigations about the Minhocao, and, if possible, to capture it for a zoological garden !

To conclude this remarkable story, we may venture to suggest whether, if any such animal really exist, which, upon the testimony produced by Fritz Müller, appears very probable, it may not rather be a relic of the race of 
gigantic armadilloes which in past geological epochs were so abundant in Southern Brazil. The little Chlamydophorus truncatus is, we believe, mainly, if not entirely, subterranean in its habits. May there not still exist a larger representative of the same or nearly allied genus, on', if the suggestion be not too bold, even a last descendant of the Glyptodonts?

SUN-SPOTS AND DECLINATION RANGES

$\mathrm{THE}$ excellent article by $\mathrm{Mr}$. Broun in a recent number of NATURE puts before us in a very clear manner the strong grounds that we have for believing in a true connection between sun-spots and terrestrial magnetism. If the argument were not already sufficiently powerful it might be yet further strengthened by bearing in mind that not merely do the most prominent inequalities march to zether in these two phenomena but the correspondence extends likewise to those waves of shorter period that ride as it were on the back of the longer ones. In a paper which is now before the Royal Society I have shown this intimacy of correspondence by comparing together the sun-spot and declination range records for the cycle extending from the minimum of 1855 to that of 1867 . All the prominent sun-spot waves are reproduced by magnetic declination waves, the latter, however, invariably lagging behind the former.

Then with regard to the long period cycle under discussion I make it to begin for sun-spots with September I 5 , 1855, which was a minimum point, and to end with March I 5, 1867, which was another minimum point. On the other hand the corresponding cycle for declination range begins with February 15,1856 , and ends with August 15, I867. Thus the length of period is the same in both; the magnetic cycle lagging, however, five months behind that for sun-spots.

I may also mention that I am at present comparing together the Prague declination ranges with the sun-spot curve determined from Hofrath Schwabe's observations, and although the comparison is not finished, I believe that this lagging behind will form a prominent feature of the results. Further back than Schwabe we cannot go, as the sun-spot records are not sufficiently accurate for this kind of work.

I am not sure, however, that I quite agree with Mr. Broun when he says "no doubt the admission of the existence of a causal connection between the two phenomena is opposed to the hypothesis, which many other facts render wholly untenable, that the magnetic variations are due to the heating action of the sun."

As far as sun-spots and declination ranges are concerned, what are the facts regarding the connection between them? These are two in number. In the first place, all the considerable oscillations of the sun-spots are reproduced in the declination-ranges. Secondly, the reproductions in the declination-ranges lag, it appears, behind the corresponding sun-spot waves. This latter fact strikes me as being rather in favour of the view which regards declination-ranges to be (like temperature-ranges) in some way the result of an influence from the sun which is of the nature of an emanation or radiation. But I will not press the point except to remark that this and a host of other questions, some of them of great importance, must wait for their solution until we shall have obtained a sufficiently complete and continuous record of solar activity, and along with it an equally complete and continuous record of the radiant power of the sun.

From the observatories already established, we have a reasonable prospect of receiving good magnetical information, and there is abundance of meteorological activity, but it is nearly, if not absolutely, impossible, from the observations already made, to tell whether the sun be hotter or colder as a whole, when there are most spots on his surface. The sooner we get to know this the better for our problem.

\section{THE ISLANDS OF ST. PAUL AND AMSTERDAM}

$A S$ is now well known, a French expedition visited these islands towards the close of 1874 for the purpose of watching the transit of Venus across the sun on December 9 of that year. M. G. de l'Isle accompanied the expedition as botanist; Dr. Rochefort, with M. Vélain to assist him, were to look after the zoological and geological departments. M. Vélain, who was a pupil of Prof. Lacaze-Duthiers has just published, in the Archives de Zoologie Expérimentale et Générale (tome 6, 1877), a most interesting account of these islands and their fauna, with in addition, a very detailed account of the collections of shells made. We are indebted to the extreme kindness of M. Vélain for the excellent illustrations which accom-

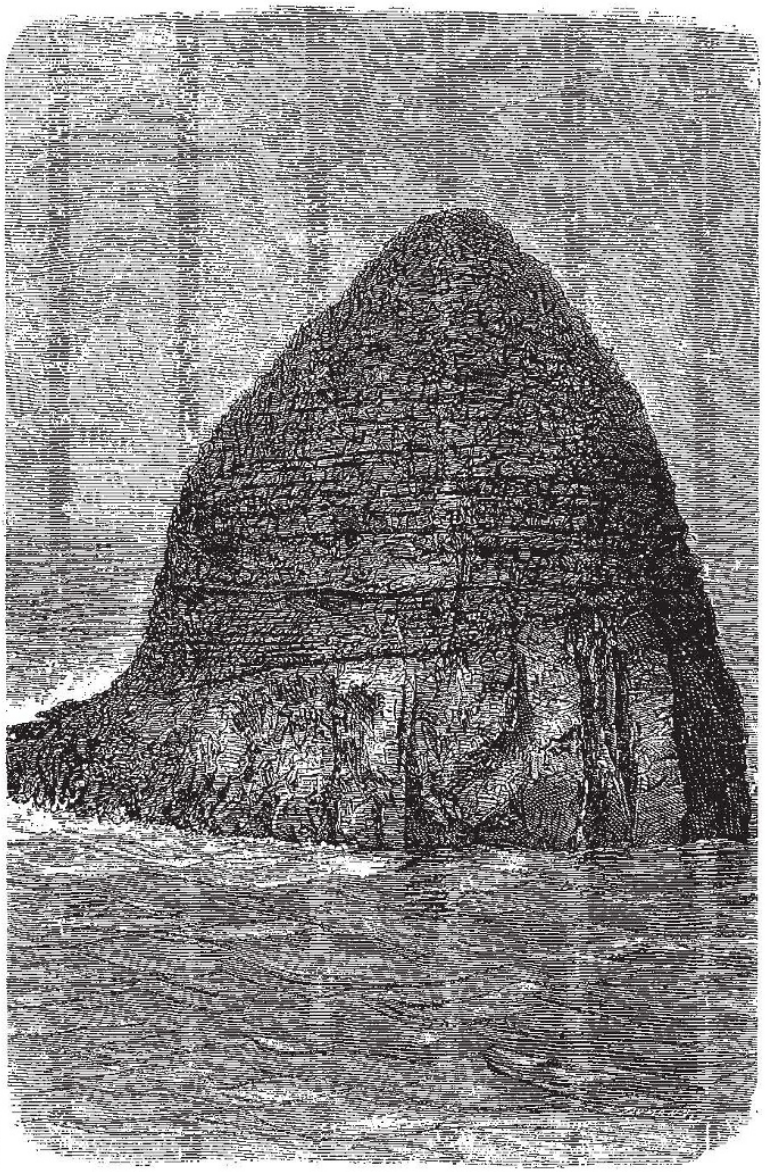

F.G. x.-Ninepin Rock.

pany this notice, which are taken from the original memoir.

If the reader wishes to fix the exact position of these curious islands he has only to trace along the line of lat. $40^{\circ} \mathrm{S}$., and about mid-way in the Southern Ocean between the Cape of Good Hope and Melbourne, near long. $80^{\circ} \mathrm{E}$., he will find them.

Their discovery has been claimed by the Dutch and the Portuguese. Placed just in the grand ocean route for all vessels leaving the Cape for Australia or China, they were doubtless, despite their isolation, long known. The history of our knowledge of them from 1522 to the present day is well, though briefly, written by M. Vélain.

The Novara called at St. Paul in 1857 , and stayed for fourteen days, and we are indebted to Hochstetter for an excellent account of the geology of the island, though 